Brit. F. industr. Med., 1967, 24, 181.

\title{
Physique and Serum Lipids of Young London Busmen in relation to Ischaemic Heart Disease
}

\author{
R. M. OLIVER ${ }^{1}$ \\ From London Transport Board
}

Earlier studies of white London busmen revealed that the ischaemic heart disease experience of conductors is better than that of drivers. Various factors which might be related to this difference have been considered, and earlier investigations have established that the physique and serum lipid concentrations of men in these two occupations are different. Since men in the younger occupational groups (25 to 29 years) showed some of these differences the suggestion has been made that conductors may be constitutionally different from drivers.

The purpose of this paper is to report a study of the physique and serum lipid concentrations of young recruits for bus driving and conducting at an earlier age than in previous studies and before any occupational factors could have exerted an effect.

Physical differences between the two groups of recruits were shown to exist. British bus driver recruits in the age group 21 to 24 years were on average $2.6 \mathrm{~cm}$. taller than British conductor recruits. This is probably because selection favours the recruitment of taller men for driving. New entrant drivers were on average $7.3 \mathrm{lb}$. (3.3 kg.) heavier, approximately $1 \mathrm{~cm}$. broader across the shoulders, and between 2 and $3 \mathrm{~cm}$. bigger round the chests and waists than conductors. It is shown that these differences are mainly secondary to differences in height. Drivers recruited from the ranks of existing conductors resembled new entrant drivers in everything but height.

British driver trainees carried more skin fat and had a tendency to higher serum lipid concentrations than conductors. This is shown to be neither secondary to differences in height nor occupationally acquired.

The importance of these findings in relation to the differing ischaemic heart disease experience of bus drivers and conductors is discussed. It is suggested that the underlying factor responsible for the known later physical differences and different ischaemic heart disease experience of London bus drivers and conductors might be a common genetic one.

Previous investigations into the health and characteristics of London bus drivers and male conductors have shown that there are certain physical differences between the two groups. This has been determined by studying existing employees (Morris, Heady, Raffle, Roberts, and Parks, 1953; Morris, Heady, and Raffle, 1956; Heady, Morris, Kagan, and Raffle, I96I).

London bus conductors are less likely than drivers to develop ischaemic heart disease and are less likely to die suddenly from the disease (Morris et al., 1953; Morris and Raffle, 1954). Morris et al. (1953, 1956) discussed the relationship of this

Received for publication January 6, 1967.

'Present address: Treasury Medical Service (Post Office Branch), Armour House, St. Martin's-le-Grand, London, E.C.I. differing ischaemic heart disease experience of London busmen to the differing exertional requirements and the physical characteristics of men in the two occupations. They were able to demonstrate that the builds of London bus drivers were different from those of conductors. Drivers were on average taller, heavier, stouter, and carried more skin fat than conductors. The relationship between these physical findings and heart disease in busmen was, however, not clear. Heady and his colleagues (I96I) showed that survivors of ischaemic heart disease episodes among drivers and conductors did not materially differ physically from those in the same occupation who had not had the disease.

Body build is influenced by many factors, one of which is undoubtedly physical activity. The studies of Morris and his colleagues on busmen and other workers (Morris, 1960; Morris et al., 1953; Morris and Crawford, 1958; Morris, Kagan, Pattison, 
Gardner and Raffle, I966), coupled with those of many other investigators (Stocks, 195I; Brunner and Manelis, 1960; Zukel, Lewis, Enterline, Painter, Ralston, Fawcett, Meredith, and Peterson, 1959; Karvonen, Rautaharju, Orma, Punsar, and Takkunen, I96I; Kahn, I963), leave little doubt that physical activity has an important beneficial relationship to ischaemic heart disease. Thus, although physical activity seems to have an important favourable influence on ischaemic heart disease in London bus conductors, the part played by physique is not certain. Furthermore, how far are the differences in physique between established drivers and conductors themselves secondary to the different physical activity in the two grades?

Heady and his colleagues (I96I) showed that drivers aged 25 to 29 years were issued with bigger uniforms than conductors, and this led to the suggestion that there were pre-existing constitutional differences between drivers and conductors. This suggestion was, however, based on the findings in men in whom the influence of occupational factors could not be ruled out. Conductors, for example, in the age group 25 to 29 years could have been employed on this work for up to 12 years. It was, therefore, important to examine in more detail the possibility of pre-existing physical differences in young bus drivers and conductors before the effects of their respective occupations could significantly influence the findings.

It was the purpose of the present study to determine by direct clinical measurement whether young recruits for bus driving and conducting exhibited differences in body builds; to establish what were the physical differences, if any; and to consider whether these differences might have a bearing on the differing ischaemic heart disease experience of men in these two occupations. Because of the relationship of serum lipids to certain aspects of body build and their possible relationship to ischaemic heart disease in London busmen (Morris, 1959; Kagan, 1960), serum lipid estimations were also undertaken.

\section{Method}

The investigation was carried out on white men selected for training by London Transport as bus drivers or bus conductors during 1960 and $196 \mathrm{I}$. It was subsequently extended to include some men training in the early part of 1964 . The men were mainly new entrant employees but some driver trainees who had previously been employed as conductors were also included. Before entering London Transport Training School every man is required to pass an initial interview and medical examination. A fairly high standard of physical fitness is necessary and certain physical standards are laid down. In addition, new entrant drivers are required to pass a preliminary driving test to ensure that they possess the basic qualities necessary to drive buses. Thus it is seen that the men who finally undergo training are a selected group of individuals. For the purposes of this investigation there was no practical way of overcoming this difficulty. A random sample of white male recruits and transfers to the grade of bus driver and bus conductor in the Central Road Services (red buses of London Transport Board) was selected. The selection was based on the day of the month in which the individual was born. The men were all within the age range 21 to 24 years inclusive. This particular age range was chosen to enable sufficient numbers of men to be compared, bearing in mind that the youngest age permitted for a London Transport bus driver was 21 years. New entrant drivers are required to have had some previous experience of driving whereas conductors transferring to the grade of drivers are not required to have had any such experience. The men could, therefore, be divided into three groups: (I) new entrant drivers-men who would like to be London bus drivers and have had some previous driving experience; (2) transfer drivers-men who were London bus conductors but wanted to be bus drivers. These men did not normally have much driving experience; and (3) new entrant conductors -men who preferred to be conductors.

The new entrant conductor group may also have included a few men who, because they lacked previous driving experience, hoped to become drivers later on, or men who were below the medical standards for driving. The inclusion of such men in this group would, however, have a diluting effect on any conductor characteristics and was not, therefore, considered to affect significantly the comparisons.

Some transfer drivers may have applied for training as drivers simply because they disliked conducting or for some other reason unconnected with a specific wish to drive. Such men would also have a diluting effect on any characteristics associated with a specific preference for driving which might be exhibited by the transfer driver group as a whole. This was not, therefore, thought to have an important effect on any group comparisons.

During the course of the investigation it was discovered that many of the recruits, particularly the conductors, were of Southern Irish nationality probably with their own national characteristics. This could have affected the comparisons made 
between groups. Men from Southern Ireland were, therefore, excluded from the investigation and this study is confined to white British trainees. To avoid bias the physical examination was carried out without prior knowledge of the man's intended occupation. The following data were recorded:

(a) height without shoes

(b) sitting height. This was measured with the subject seated and is the distance between the plane of the seat and the top of the head

(c) weight

(d) chest circumference measured at full inspiration and full expiration approximately $2 \mathrm{~cm}$. below the nipples

(e) waist circumference measured at trouser waist level with the subject standing relaxed and breathing normally

(f) bi-acromial diameter. This is the distance between the tips of the acromial processes

(g) skinfold thickness. This was measured using Harpenden skinfold calipers (Tanner and Whitehouse, 1955) at three sites-triceps, subscapular, and supra-iliac

(h) serum lipids

(I) total cholesterol (by the method of Abell, Levy, Brodie, and Kendall, 1952)

(2) low density lipoproteins; a modified ultracentrifugal method (Lindgren and Gofman, 1957) using refractive index increment $\mathrm{I} \cdot 5 \mathrm{I} \times \mathrm{IO}^{-3} / \mathrm{g} . / 100 \mathrm{ml}$. (Hanig and Shainoff, 1956)

(3) calculation of the concentration of molecules Sf. 0-12 and Sf. 12-400 using (2) and the total cholesterol in the low density fraction in the regression equations supplied by Lindgren and Gofman (1957).

\section{Results}

A total of 228 British trainees was examined. A summary of the results is shown in Table I. The statistical analysis appears in Appendix Tables I and II (pp. I87 and I88).

Height and Weight New entrant drivers were $2.6 \mathrm{~cm}$. taller on average than new entrant conductors $(\mathbf{P}=0.01)$, most of this increased height being accounted for by increased leg length. Transfer drivers were not taller than conductors.

New entrant drivers were on average $7.3 \mathrm{lb}$. (3.3 kg.) heavier $(P=0.01)$, and transfer drivers 4.2 lb. ( $1.9 \mathrm{~kg}$.) heavier $(P=0.2 \mathrm{I})$, than new entrant conductors.

Girth Drivers were shown to be bigger round the chest and waist than conductors. The mean
TABLE I

Differences in Physique and Serum Lipids Between Groups of Trainee Busmen (MEans Rounded to Nbarest WHOLE NUMBER)

\begin{tabular}{|c|c|c|c|}
\hline & $\begin{array}{c}\text { New } \\
\text { Entrant } \\
\text { Drivers }\end{array}$ & $\begin{array}{l}\text { Transfer } \\
\text { Drivers }\end{array}$ & $\begin{array}{c}\text { Nerv } \\
\text { Entrant } \\
\text { Conductors }\end{array}$ \\
\hline $\begin{array}{l}\text { Height (cm.) } \\
\text { Sitting height (cm.) } \\
\text { Weight (lb.) } \\
\quad \text { (kg.) } \\
\text { Chest circumference } \\
\text { (cm.) } \\
\text { Inspiration } \\
\text { Expiration } \\
\text { Waist circumference } \\
\text { (cm.) } \\
\text { Bi-acromial diameter } \\
\text { (cm.) } \\
\text { Skinfold thicknesses }{ }^{1} \\
\text { (mm.) } \\
\text { Triceps } \\
\text { Subscapular } \\
\text { Supra-iliac } \\
\text { Total } \\
\text { Serum lipids } \\
\text { Cholesterol } \\
\text { (mg./100 ml.) } \\
\text { Low density lipoproteins } \\
\text { (mg./100 ml.) } \\
\text { Fraction Sf. O-12 (mg.) } \\
\text { Fraction Sf. I2-400 } \\
\text { (mg.) }\end{array}$ & $\begin{array}{l}92 \\
86 \\
78 \\
40\end{array}$ & $\begin{array}{r}195 \\
498 \\
318 \\
\\
176\end{array}$ & $\begin{array}{l}90 \\
84 \\
\\
75 \\
\\
39\end{array}$ \\
\hline
\end{tabular}

Nos. of observations and statistical analysis are shown in Appendix Tables I and II (pp. 187 and I88).

${ }^{1}$ Total skinfold thicknesses were derived from the sum of the other three skinfolds. Thicknesses transformed using formula $Z=100 \log _{10}$ (reading in $0.1 \mathrm{~mm}$. minus 18) (Edwards, Hammond, Healy, Tanner, and Whitehouse, 1955).

circumferences of the chests of new entrant drivers were on full inspiration $2 \cdot 2 \mathrm{~cm}$. greater and on full expiration $2.7 \mathrm{~cm}$. greater than those of new entrant conductors. Both these differences are statistically significant $(P<0 \cdot 01)$. Similarly, the inspiratory and expiratory chest circumferences of transfer drivers were respectively $1 \cdot 7 \mathrm{~cm}$. and $1 \cdot 8$ $\mathrm{cm}$. greater than those of conductors $(P=0.06$ and $0.05)$. The mean waist measurements of new entrant and transfer drivers were respectively $2.6 \mathrm{~cm}$. and $2.9 \mathrm{~cm}$. greater than those of conductors ( $P=0.02$ in both instances).

Shoulder Breadth The two driver groups, as judged by the bi-acromial diameter, were broader across the shoulders than conductors, the difference being approximately $\mathrm{I} \mathrm{cm}$. in each instance. Although the difference was small it nevertheless is highly significant statistically $(\mathbf{P}=0.0002)$. 
Skinfold Thicknesses Drivers, especially the transfer drivers, had greater mean skinfold thicknesses than conductors. This was most marked for the subscapular, supra-iliac, and total skinfolds. The differences between any of the triceps skinfold thicknesses are not statistically significant.

Serum Lipids None of the differences is statistically significant. Previous studies (Morris, 1959; Kagan, 1960) had suggested that a higher concentration of serum cholesterol might be expected in the driver groups and it is noteworthy that, despite the absence of statistical significance, the results in this study followed the expected pattern.

\section{Discussion}

It is seen that there are important physical differences between young bus driver and conductor recruits. Drivers were bigger round the chest and waist than conductors and were broader across the shoulders. Drivers were heavier than conductors but the driver trainees who had previously been conductors (that is the 'transfer' drivers) were only slightly heavier.

Another important characteristic was that the drivers had more subcutaneous fat than the conductors. This is common to the new entrant and transfer drivers and is unlikely to be the result of any selection by London Transport. The increased mean serum lipid concentrations of both driver groups are probably related to increased obesity. Minor degrees of obesity, therefore, seem to be associated with a preference for driving rather than conducting buses. Even those more obese men who are already conductors because they are not old enough or lack the experience to become drivers also choose to train as drivers even if they have never in their lives driven before. The reason for this is not known. It may be an associated inherent wish for a job involving little exertion or some as yet undetermined psychological characteristic which makes a man seek a job away from close contact with other people. Possibly it is a desire to be 'in charge' or simply ambition, since for a conductor to become a driver is promotion.

The height of new entrant drivers was significantly greater than that of conductors. On the other hand, the mean height of transfer drivers was almost identical with that of conductors. Thus, although in many of the other physical factors the transfer drivers closely resembled new entrant drivers, in height they showed a marked and statistically significant difference from their new entrant colleagues $(P<0.05)$. From this it seems likely that height may play an important part in the preliminary selection for employment of drivers and conductors. It was the policy of London Transport to reject for employment as conductors men who were over $6 \mathrm{ft}$. $(\mathrm{I} \cdot 8 \mathrm{~m}$.) tall. Drivers must be able to reach the driving pedals. This may influence the selection of longer-legged men for driving with a consequent greater overall mean height for this group. The data obtained from the new entrant driver group in this study supported this view.

Thus, tall, long-legged men are selected or select themselves for initial recruitment as drivers and tall men are rejected or do not apply for employment as conductors. This explains why transfer drivers, who had first been selected and served as conductors, resembled new entrant conductors in their mean height.

It is important to consider how far height selection may be responsible for the other physical differences between drivers and conductors. Clearly, it is not an important factor in explaining the other differences between transfer drivers and conductors as the mean heights of these two groups were similar. It appeared that the fatter, stouter, broader conductors like to become drivers. In the new entrant drivers where the influence of height on other characteristics could be important it was thought advisable to compare new entrant drivers and conductors of similar height. In this study sufficient numbers for a useful conclusion to be drawn were obtained by comparing men within an intermediate height range, that is, men whose height was $173 \mathrm{~cm}$. or more but less than $180 \mathrm{~cm}$. The mean heights of drivers and conductors within this height range differed by only $0.3 \mathrm{~cm}$., which was not significant $(P>0.5)$. The results of the comparison made in this way are shown in Table II and Appendix Table III (p. I88).

In contrast to the transfer drivers the new entrant drivers did not show such marked differences from conductors of similar height. The mean chest and waist circumferences and the bi-acromial diameter of new entrant drivers were only slightly greater than those of conductors of similar height. The differences are not statistically significant. Similarly, new entrant drivers were only $\mathrm{I} \cdot 3 \mathrm{lb}$. $(0.6 \mathrm{~kg}$.) heavier than conductors in this intermediate height range. This also is not statistically significant. The skinfold thicknesses did, however, show marked differences. New entrant drivers carried considerably more skin fat than new entrant conductors of similar height. This difference of nearly $5 \mathrm{~mm}$. in the total of the three skinfolds is statistically significant $(\mathbf{P}<0.05)$. The increased skin fat 
TABLE II

Differences in Important Physical Characteristics betweEn NeW ENTRANT DRIVERS aNd CoNDUCtors WITHIN thr Height RaNge 173 CM. TO I8O CM. (MEANS ROUNDED to NEAREST WHOLE NUMBER)

\begin{tabular}{l|c|c}
\hline & $\begin{array}{c}\text { New } \\
\text { Entrant } \\
\text { Drivers }\end{array}$ & $\begin{array}{c}\text { New } \\
\text { Entrant } \\
\text { Conductors }\end{array}$ \\
\hline Height (cm.) & 175 & 175 \\
Chest circumference & 92 & 91 \\
$\quad$ (inspiration) (cm.) & 77 & 76 \\
Waist circumference (cm.) & 40 & 40 \\
Bi-acromial diameter (cm.) & 149 & 148 \\
Weight (lb.) & 68 & 67 \\
Total skinfold thickness (mm.) & 23 & 19 \\
Serum cholesterol (mg./100 ml.) & 195 & 182 \\
& & \\
\hline
\end{tabular}

The full results and statistical analysis are shown in Appendix Table III. Total skinfold as in Table I.

probably explains the greater mean weight of new entrant drivers in this group and is also likely to be in part responsible for the difference in chest and waist circumferences and in shoulder breadth.

It is of interest in these men of similar heights that the serum cholesterol of new entrant drivers was noticeably greater than that of the conductors. The difference is not statistically significant but is greater than that demonstrated when all conductors and drivers irrespective of height are compared. It is also noteworthy that the mean serum cholesterol of this intermediate height group of new entrant drivers was the same as that of the transfer driver group.

\section{Conclusions}

It is apparent that British men with certain physical characteristics choose, or are chosen, to become drivers as opposed to conductors. The most obvious characteristic governing this choice is the height of the individual. It is this which is responsible for the selection as new entrant drivers of the taller 'bigger' men. Height is not important in the selection of drivers from the ranks of existing conductors. Such transfer driver trainees show many of the other physical characteristics of their new entrant colleagues. Thus the more 'stocky' conductors tend to transfer to driving duties.

The present study suggests that the differences in physical characteristics of bus drivers and conductors, which Morris and his colleagues demonstrated to be present in older employees, are already present to some extent in men before they take up their employment. Skeletal build, particularly height, is almost certainly genetically determined. This genetic influence may, therefore, be fundamentally responsible for the selection of taller men as drivers. Similarly, bi-acromial diameter is mainly a skeletal factor probably genetically determined. Perhaps of greater significance in relation to ischaemic heart disease is the fact that men with greater amounts of skin fat irrespective of height prefer to become drivers. This obesity is clearly not occupationally acquired since conductors who wish to be drivers also show this feature. It is probably a constitutional characteristic of the individual, although it is not possible to rule out the effect of previous occupation before joining London Transport. It is interesting to note that small but as yet insignificant differences in the serum lipids of drivers and conductors were beginning to appear in line with those known to exist in older busmen and at a time when the differing exertional and other requirements of their occupations could not have had an effect.

Since obesity and raised serum cholesterol are related to a greater incidence of ischaemic heart disease, these findings may have a bearing on the subsequent differing ischaemic heart disease experience of bus drivers and conductors.

Whatever the reason, whether it be self-selection or selection by the employer or some other unknown factor, it has been shown that British young men in their early 20 sho wish to start driving buses are physically different from those who prefer to be conductors. It is likely that these pre-existing differences, and not later occupational factors, are fundamentally responsible for the known physical . differences in older employees. It is suggested, and there is some evidence from this study, that the underlying factor is genetic. If this is so, then this factor could also be fundamentally responsible for the differing ischaemic heart disease experience of men in these two occupations even if various environmental influences such as physical activity later accelerate or retard the process. Although occupation may predispose to ischaemic heart disease, this study supports a view that inherited characteristics, one of which may be susceptibility to heart disease, may predispose to a particular occupation.

I should like to thank Dr. L. G. Norman, Chief Medical Officer, London Transport Board, for permission to undertake this study and for much encouragement and advice. I am also grateful for the co-operation of the Staff and Welfare Offlcer and many other of my former colleagues in London Transport, particularly Mr. J. S. Chapman for his help with the statistical analysis of the results. 
186

R. M. Oliver

I should like to acknowledge the assistance of Professor A. C. Dornhorst and Dr. T. R. Pilkington, of St. George's Hospital Medical School, with the blood examinations and to thank Professor J. N. Morris, of the Medical Research Council's Social Medicine Research Unit, for his advice.

This paper is based on some of the material used in the preparation of a thesis accepted for the M.D. degree of the University of London.

REFERENCES

Abell, L. L., Levy, B. B., Brodie, B. B., and Kendall, F. E. (1952). F. biol. Chem., 195, 357.

Brunner, D., and Manelis, G. (1960). Lancet, 2, 1049.

Edwards, D. A. W., Hammond, W. H., Mealy, M. J. R., Tanner, J. M., and Whitehouse, R. H. (1955). Brit. f. Nutr., 9, 133.

Haig, M., and Shainoff, J. R. (1956). F. biol. Chem., 219, 479. Heady, J. A., Morris, J. N., Lagan, A., and Raffle, P. A. B. (1961). Brit. F. prev. soc. Med., 15, 143.
Kagan, A. (1960). Proc. roy. Soc. Med., 53, 18.

Kahn, H. A. (1963). Amer. F. publ. Hlth, 53, 1058.

Karvonen, M. J., Rautaharju, P. M., Orma, E., Punsar, S., and Takkunen, J. (1961). f. occup. Med., 3, 49.

Lindgren, F. T., and Gofman, J. W. (1957). Bull. Schweiz. ARad. med. Wist, 13, 152.

Morris, J. N. (1959). Arch. intern. Med., 104, 903.

- (1960). Mod. conc. cardiovasc. Dis., 29, 625 .

-, and Crawford, M. D. (1958). Brit. med. F., 2, 1485.

—, Heady, J. A., and Raffle, P. A. B. (1956). Lancet, 2, 569.

,,,--- Roberts, C. G., and Parks, J. W. (I953). Ibid., 2, I053, 1111.

-, Kagan, A., Pattison, D. C., Gardner, M. J., and Raffle, P. A. B. (1966). Ibid., 2, 553.

, and Raffle, P. A. B. (1954). Brit. F. industry. med., I1, 260. Stocks, P. (195I). Lancet, 1,351 .

Tanner, J. M., and Whitehouse, R. H. (1955). Amer. F. phys. Anthrop, nos., 13, 743.

Zukel, W. J. Lewis, R. H., Interline, P. E., Painter, R. C., Ralston, L. S., Fawcett, R. M., Meredith, A. P., and Peterson, B. (1959). Amer. F. publ. Heth, 49, 1630.

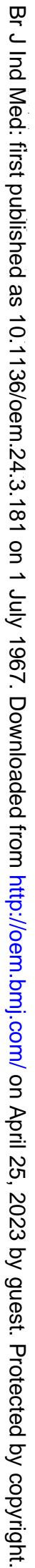

(Appendix pp. 187 and 188) 


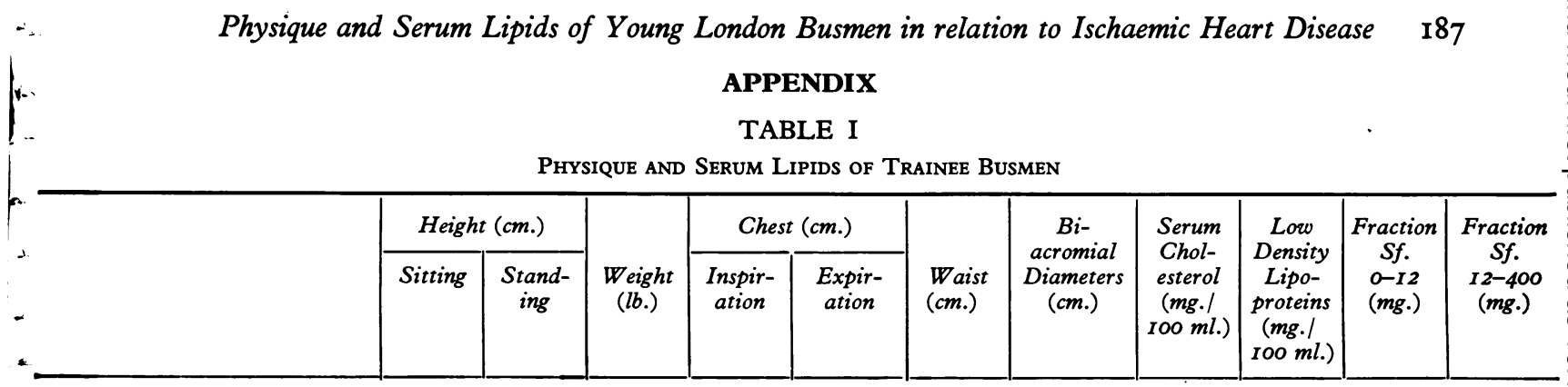

New Entrant Drivers v. New Entrant Conductors

Drivers

Mean

Standard deviation

Conductors

Mean

Standard deviation

- Difarence between means

(Arivers-conductors) ' $t$ '

Probability of ' $t$ ' occurring by

chance if no real difference $(P)$

\begin{tabular}{|rr|r|rr|}
92.9 & 175.4 & 151.7 & 92.9 & 86.3 \\
2.9 & 6.4 & 20.8 & 5.3 & 5.6 \\
& & & & \\
91.9 & 172.8 & 144.4 & 90.0 & 83.6 \\
2.9 & 6.0 & 17.4 & 5.1 & 4.8 \\
+1.0 & +2.6 & +7.3 & +2.2 & +2.7 \\
+2.23 & +2.74 & +2.48 & +2.77 & +3.38 \\
0.03 & 0.01 & 0.01 & 0.01 & 0.001
\end{tabular}

\begin{tabular}{r|r|r|r|r|r}
77.7 & 39.9 & 194.8 & 510.7 & 314.8 & 188.6 \\
7.5 & 2.5 & 38.9 & 134.9 & 48.2 & 91.8 \\
& & & & & \\
75.1 & 39.1 & 187.3 & 486.3 & 309.7 & 176.0 \\
6.1 & 1.5 & 34.0 & 153.1 & 51.5 & 101.4 \\
& & & & & \\
+2.6 & +0.8 & +7.5 & +34.4 & +5.1 & +12.6 \\
+2.46 & +2.46 & +1.34 & +08.4 & +0.51 & +0.64 \\
0.02 & 0.02 & 0.18 & 0.40 & 0.61 & 0.52 \\
\hline
\end{tabular}

- Tremsfer Drivers v. New Entrant Conductors

Transfers

Mean

Standard deviation

Conductors

Mean

Standard deviation

Difierence between means

(transfers-conductors) ' $\mathrm{t}$ '

Probability of ' $t$ ' occurring by chance if no real difference $(P)$

\begin{tabular}{|c|c|c|c|c|c|c|c|c|c|c|}
\hline $\begin{array}{r}91 \cdot 9 \\
2 \cdot 4\end{array}$ & $\begin{array}{r}172 \cdot 9 \\
4.9\end{array}$ & $\begin{array}{r}148 \cdot 6 \\
20 \cdot 6\end{array}$ & $\begin{array}{r}91 \cdot 7 \\
5 \cdot 0\end{array}$ & $\begin{array}{r}85 \cdot 4 \\
5 \cdot 4\end{array}$ & $\begin{array}{r}78 \cdot 0 \\
7 \cdot 3\end{array}$ & $\begin{array}{r}40 \cdot 1 \\
I \cdot 4\end{array}$ & $\begin{array}{r}194.6 \\
33.6\end{array}$ & $\begin{array}{l}498 \cdot 1 \\
140 \cdot 5\end{array}$ & $\begin{array}{r}317 \cdot 5 \\
51 \cdot 5\end{array}$ & $\begin{array}{r}175.9 \\
96.4\end{array}$ \\
\hline $\begin{array}{r}91 \cdot 9 \\
2 \cdot 9\end{array}$ & $\begin{array}{r}172.8 \\
6.0\end{array}$ & $\begin{array}{r}144.4 \\
17 \cdot 4\end{array}$ & $\begin{array}{r}90 \cdot 0 \\
5 \cdot 1\end{array}$ & $\begin{array}{r}83 \cdot 6 \\
4 \cdot 8\end{array}$ & $\begin{array}{r}75 \cdot 1 \\
6 \cdot 1\end{array}$ & $\begin{array}{r}39 \cdot 1 \\
1 \cdot 5\end{array}$ & $\begin{array}{r}187.3 \\
34.0\end{array}$ & $\begin{array}{l}486 \cdot 3 \\
153 \cdot 1\end{array}$ & $\begin{array}{r}309 \cdot 7 \\
51 \cdot 5\end{array}$ & $\begin{array}{l}176 \cdot 0 \\
101 \cdot 4\end{array}$ \\
\hline $\begin{array}{l}0.00 \\
0.00\end{array}$ & $\begin{array}{l}+0.1 \\
+0.10\end{array}$ & $\begin{array}{l}+4 \cdot 2 \\
+1 \cdot 25\end{array}$ & $\begin{array}{l}+\mathrm{r} \cdot 7 \\
+\mathrm{I} \cdot 88\end{array}$ & $\begin{array}{l}+\mathrm{I} \cdot 8 \\
+\mathrm{I} \cdot 98\end{array}$ & $\begin{array}{l}+2.9 \\
+2.44\end{array}$ & $\begin{array}{l}+1.00 \\
+3.81\end{array}$ & $\begin{array}{l}+7 \cdot 3 \\
+1 \cdot 18\end{array}$ & $\begin{array}{l}+11.8 \\
+0.38\end{array}$ & $\begin{array}{l}+7.8 \\
+0.72\end{array}$ & $\begin{array}{l}-0.1 \\
-0.005\end{array}$ \\
\hline I. 00 & 0.92 & 0.21 & 0.06 & 0.05 & 0.02 & 0.0002 & 0.24 & 0.70 & 0.47 & 0.99 \\
\hline
\end{tabular}

New Entrant Drivers v. Transfer Drivers

Drivers

Mean

Standard deviation

- Transfers

Mean

Standard deviation

D rence between means

- Trivers-transfers)

' ' $\mathrm{t}$ '

Fiobability of ' $t$ ' occurring by chance if no real difference $(P)$

\begin{tabular}{|rr|r|rr|}
92.9 & 175.4 & 151.7 & 92.2 & 86.3 \\
2.9 & 6.4 & 20.8 & 5.3 & 5.6 \\
& & & & \\
91.9 & 172.9 & 148.6 & 91.7 & 85.4 \\
2.4 & 4.9 & 20.6 & 5.0 & 5.4 \\
+1.0 & +2.5 & +3.1 & +0.5 & +0.9 \\
+2.09 & +2.45 & +0.86 & +0.56 & +0.94 \\
& & & & \\
0.4 & 0.02 & 0.37 & 0.58 & 0.34
\end{tabular}

\begin{tabular}{c|c|}
$77 \cdot 7$ & \\
$7 \cdot 5$ & \\
$78 \cdot 0$ & \\
$7 \cdot 3$ & \\
-0.3 & \\
-0.23 & $-0 \cdot$ \\
0.82 &
\end{tabular}

\begin{tabular}{r|r|r|r|r}
39.9 & 194.8 & 510.7 & 314.8 & 188.6 \\
2.5 & 38.9 & 134.9 & 48.2 & 91.8 \\
& & & & \\
40.1 & 194.6 & 498.1 & 317.5 & 175.9 \\
1.4 & 33.6 & 140.5 & 51.5 & 96.4 \\
-0.2 & +0.2 & +12.6 & -2.7 & +12.7 \\
-0.56 & +0.03 & +0.47 & -0.27 & +0.68 \\
0.58 & 0.98 & 0.64 & 0.79 & 0.50
\end{tabular}

(1)

Nos. of observations: new entrant drivers, 97; transfer drivers, 52; new entrant conductors, 79 (except for serum cholesterol estimations where the numbers were 87,50 , and 79 respectively, and for the lipid fractions 57,49 , and 44 respectively). 
TABLE II

Skinfold Thicknesses of Trainee Busmen using Transformation 100 LoG $_{10}$ (Reading IN $0 \cdot 1$ MM.-18)

\begin{tabular}{|c|c|c|c|c|c|}
\hline & & $\begin{array}{c}\text { Triceps } \\
\text { Skinfold } \\
\text { (mm.) }\end{array}$ & $\begin{array}{c}\text { Subscapular } \\
\text { Skinfold } \\
(\mathrm{mm} .)\end{array}$ & $\begin{array}{c}\text { Supra-iliac } \\
\text { Skinfold } \\
(\mathrm{mm} .)\end{array}$ & $\begin{array}{c}\text { Total } \\
\text { Skinfold } \\
(\mathrm{mm} .)\end{array}$ \\
\hline $\begin{array}{l}\text { New Entrant Drivers v. } \\
\text { New Entrant Conductors } \\
\text { Difference between mean } \\
\text { ' } t \text { ' } \\
\text { Probability of ' } t \text { 'occurring } \\
\text { (P) }\end{array}$ & $\begin{array}{l}\text { Drivers } \\
\text { Mean } \\
\text { Standard deviation } \\
\text { Conductors } \\
\text { Mean } \\
\text { Standard deviation } \\
\text { drivers-conductors) } \\
\text { chance if no real difference }\end{array}$ & 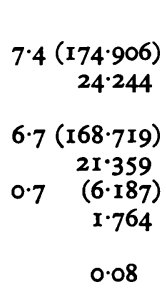 & $\begin{array}{c}10.3(193.331) \\
19.415 \\
9.3(187.425) \\
17.978 \\
1.0 \quad(5.906) \\
2.061 \\
\\
0.04\end{array}$ & $\begin{array}{r}8.9(185 \cdot 404) \\
30 \cdot 772 \\
7 \cdot 2(173 \cdot 371) \\
29 \cdot 082 \\
1 \cdot 7 \quad(12.033) \\
2.629 \\
0.01\end{array}$ & $\begin{array}{r}26.6(232 \cdot 799) \\
25.938 \\
\\
23.5(225 \cdot 900) \\
21 \cdot 071 \\
3.1 \quad(6.899) \\
1.894 \\
0.06\end{array}$ \\
\hline $\begin{array}{l}\text { Transfer Drivers v. } \\
\text { New Entrant Conductors } \\
\text { Difference between mean } \\
\text { Probability of ' } t \text { ' occurring } \\
\text { (P) }\end{array}$ & $\begin{array}{l}\text { Transfers } \\
\text { Mean } \\
\text { Standard deviation } \\
\text { Conductors } \\
\text { Mean } \\
\text { Standard deviation } \\
\text { transfers-conductors) } \\
\text { y chance if no real difference }\end{array}$ & 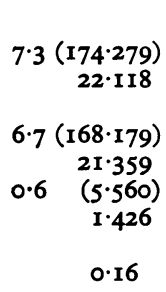 & $\begin{array}{c}\text { II.4 }(198 \cdot 407) \\
20.459 \\
\\
9.3(187.425) \\
17.978 \\
2 \cdot 1 \quad(10.982) \\
3.212 \\
0.002\end{array}$ & $\begin{array}{c}9.2(186.896) \\
31.627 \\
\\
7.2(173 \cdot 371) \\
29 \cdot 028 \\
2.0 \quad(13.525) \\
2.498 \\
0.01\end{array}$ & $\begin{array}{r}28.6(236.532) \\
23.052 \\
\\
23.5(225.900) \\
21.071 \\
5.1 \quad(10.632) \\
2.700 \\
0.008\end{array}$ \\
\hline $\begin{array}{l}\text { New Entrant Drivers v. } \\
\text { Transfer Drivers } \\
\text { Difference between mean } \\
\text { Probability of ' } t \text { ' occurring } \\
\text { (P) }\end{array}$ & $\begin{array}{l}\text { Drivers } \\
\text { Mean } \\
\text { Standard deviation } \\
\text { Transfers } \\
\text { Mean } \\
\text { Standard deviation } \\
\text { drivers-transfers) } \\
\text { y chance if no real difference }\end{array}$ & 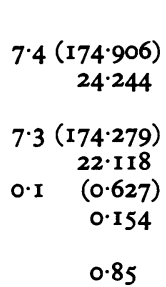 & $\begin{array}{r}10.3(193.33 I) \\
19.415 \\
\\
11 \cdot 4(198.407) \\
20.459 \\
-I \cdot I(-5.076) \\
-1.483 \\
0.14\end{array}$ & $\begin{array}{r}8.9(185.404) \\
30.772 \\
\\
9.2(186.896) \\
31.627 \\
-0.3(-1.492) \\
-0.278 \\
0.78\end{array}$ & $\begin{array}{r}26.6(232 \cdot 799) \\
25.938 \\
\\
28.6(236 \cdot 532) \\
23.052 \\
-2.0(-3.733) \\
-0.864 \\
0.38\end{array}$ \\
\hline
\end{tabular}

Transformed values in brackets

Nos. of observations: new entrant drivers, 97; transfer drivers, 52 ; new entrant conductors, 79.

TABLE III

Comparison of Physical Characteristics of New Entrant Drivers and Conductors WITH HEIGHT RANGE $173 \mathrm{CM}$. TO $180 \mathrm{CM}$.

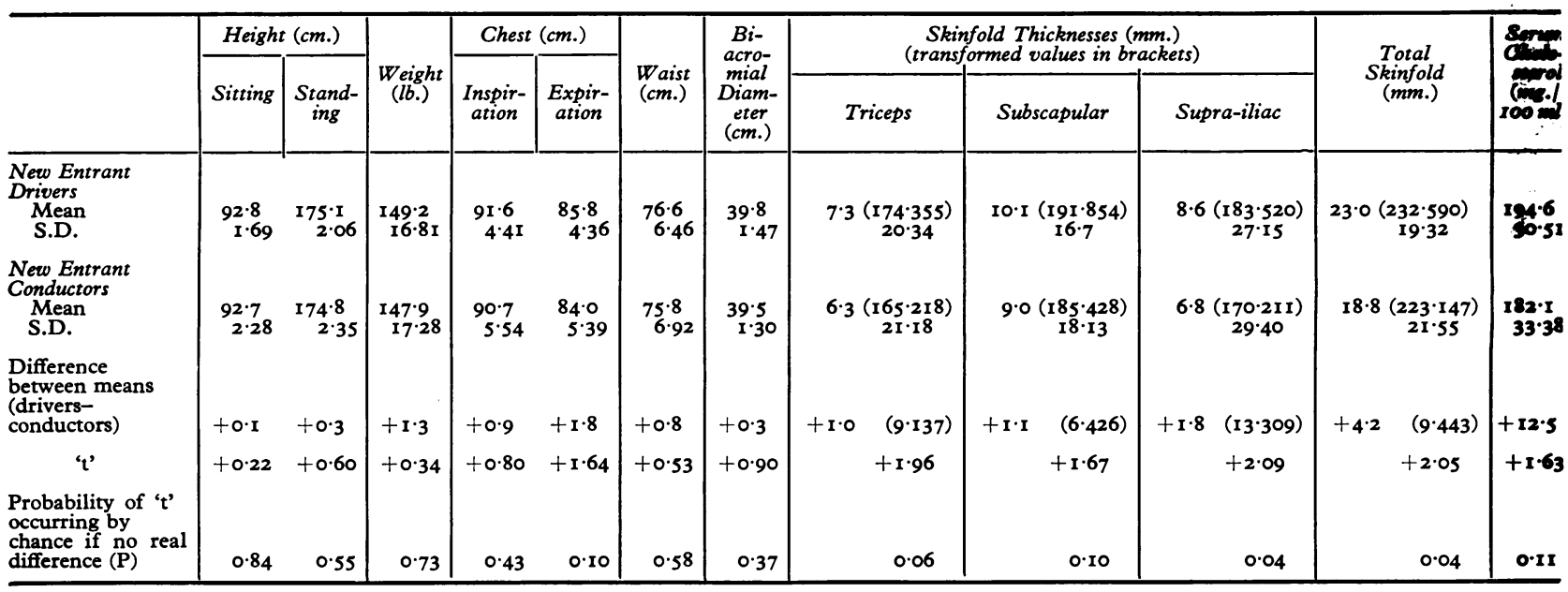

Data on 42 new entrant drivers and 39 new entrant conductors (except for cholesterol estimations where numbers were 36 and 37 respectively) Skinfolds transformed as in Appendix Table II: transformed values shown in brackets. 